\title{
Leadership, social determinants of health and health equity: the case of Costa Rica
}

\author{
Epsy Campbell Barr ${ }^{1}$ and Michael Marmot ${ }^{2}$
}

Suggested citation Campbell Barr E and Marmot M. Leadership, social determinants of health and health equity: the case of Costa Rica. Rev Panam Salud Publica. 2020;44:e139. https://doi.org/10.26633.RPSP.2020.139

ABSTRACT

Costa Rica has long been a country of special interest in the Americas and in global health because of its good health. The United Nations Development Programme ranks countries according to their level of human development based on life expectancy, education and national income. Although Costa Rica is ranked at 63 and classified as 'High', in terms of health it belongs in the 'Very High' group. In 2018 mean life expectancy for the 'Very High' countries was 79.5, while in Costa Rica it was 80. In 2018, under five mortality was 8.8/1000 live births, lower than countries ranked in the 'Very High' human development group. Expected years of schooling in Costa Rica is 15.4, closer to the average, 16.4 years, of the 'Very High' human development group than the average of the 'High' group. The country is much healthier than would be predicted by its national income; rather, other features of society's development are likely to have played a key role in the development of good health. These include (i) the decision to cease investment in national defence, which freed up money to invest in health, education and the welfare of the population; (ii) the decision to create a universal health system financed by the State, employers and workers in the 1940s; and (iii) the educational system, that generated opportunities to lift important sectors of the population out of poverty, allowing them to have basic sanitary conditions that increase their possibilities to live longer and in better conditions. Despite these advances, inequalities in terms of income and social conditions persist, presenting challenges in the field of health, particularly for lower-income populations and those of African and indigenous descent. These inequalities must be addressed using decisions based on scientific evidence, a greater use of disaggregated data to reveal progress in addressing these inequalities, and with a broader articulation of the health sector with policies that act on the social determinants of health.

Keywords Health equity; social determinants of health; human development; life expectancy; Costa Rica.

Costa Rica has long been a country of special interest in the Americas particularly, and in global health more generally, because of its good health. The United Nations Development Programme ranks countries according to their level of human development, based on life expectancy, education and national income. Norway tops the list at 1, Niger trails at 189 in the 2018 report (1). The first 58 countries are classified as 'Very High Human Development'. Costa Rica, ranked at 63, is classified as 'High', but in terms of health it belongs in the 'Very High' group. In 2018 mean life expectancy for the 'Very High' countries was 79.5. In Costa Rica it was 80, fully 4 years longer than the average, 76, for the 'High' group.

Government of the Republic of Costa Rica, San Jose, Costa Rica
Costa Rica's good health illustrates an important point about human development. To put it simply, money isn't everything. To be sure, the countries in the 'Low' Human Development group -countries with low average life expectancy, 60.8- had (in 2018) an average Gross National Income per person of $\$ 2,521$ at Purchasing Power Parities (PPP), compared to $\$ 14,999$ in the 'High' group, and $\$ 40,041$ in the 'Very High' group. If Costa Rica were ranked only by Gross National Income per person, it would rank 15 places worse than its 63 ranking on the Human Development Index. If we took life expectancy as the criterion, Costa Rica would rank 31 places better. It is much healthier than would be predicted by its national income.

\footnotetext{
2 University College London Institute of Health Equity $₫$ m.marmot@ucl.ac.uk
} 
Costa Rica's good health at levels of national income far below the average for countries in the 'Very High' group illustrates a general point. The Pan American Health Organization Commission on Equity and Health Inequalities in the Americas drew attention to the Preston curve which shows a steep relation between national income and life expectancy for countries at low levels of national income. But, from Costa Rica's level of national income, $\$ 14,636$ at PPP, on up, there is little relation between national income and life expectancy (2). Other features of society's development are more important. Hence the interest in how Costa Rica achieved its remarkable health record.

\section{DEVELOPMENT SINCE COSTA RICA'S 1949 CONSTITUTION}

Three notable changes are likely to have played a key role in the development of good health in Costa Rica. First, was the decision to cease investment in national defence. It was at the same time a signal of national priorities and freed up money to invest in health, education and the welfare of the population. Costa Rica, this decision said, is a country that invests in the well-being of its people, not using the military against them, or others.

Related to this powerful statement of intent was the second important policy: Costa Rica's decision to create a universal health system financed by the State, employers and workers in the 1940s. The Costa Rican health system is based on solidarity and requires the Costa Rican State to invest in health, but it also mandates joint responsibility with all actors in the public and private spheres, with workers and employers. The creation of the Costa Rican Social Security Fund marks the country out as special in providing public health coverage.

Third, the educational system generated important opportunities to lift important sectors of the population out of poverty, allowing them to have basic sanitary conditions that increase their possibilities not only to live longer in years, but also to live in better conditions. Education provided opportunities for health promotion.

Costa Rica sees itself as a developing country. We have already referred to life expectancy figures that would, taken alone, qualify it to be in the 'Very High' human development group. Under five mortality rates globally range from 2/1000 live births in Iceland, to 127 in Chad. In 2018, under five mortality in Costa Rica was 8.8/1000 live births -lower than countries such as Uruguay and Argentina that are ranked in the 'Very High' human development group. Expected years of schooling in Costa Rica is 15.4, closer to the average, 16.4 years, of the 'Very High' human development group than the average of the 'High' group. In ways that matter to human well-being, education and health, Costa Rica is a success.

\section{THE CHALLENGE OF INEQUALITIES}

As with most countries in Latin America, Costa Rica is marked by large inequalities, in income and social conditions. This poses challenges for health, including worse health of the poor, and for people of African descent. These health disadvantages, and those for Indigenous peoples, are seen throughout the Region.

All countries face these problems of health inequity. The Government of Costa Rica promoted a series of actions that has had a general impact on the population. The first big decision was to put the issue of the health of residents at the center of the debate. That is to say, that all economic decisions were subject to scrutiny of their impact on health issues. The Government of Costa Rica was able to do this precisely because of its tradition of having a robust health system. Second, and this should not need comment, decisions are based on science, with reliable empirical information. This has been an absolutely central element. In the future there will be a larger focus on disaggregated results to reveal progress in tackling health inequities. It is a matter of considerable regret that basing policy on sound science is not universally practiced among countries. Third, the Government of the Republic has taken affirmative actions in favor of women. There has been success in reducing rates of adolescent pregnancy. But the excess among girls of African descent remains a particular challenge. It is likely to be linked to the high rates of poverty in girls and women of African descent. Fourth, mental health is now firmly on the agenda. A series of decisions have been made that are fundamentally focused on recommendations to families and individuals so that the issue of mental health is not left out of the conversation on holistic health.

Related to the above, Costa Rica has promoted two protocols: one aimed specifically at the indigenous population and the other for the Afro-descendant population. They are guidelines for the health sector towards the indigenous population and guidelines for the Afro-descendant population. Progress will also require the health sector to be coupled with inclusive policies on social determinants of health more generally.

\section{COLLABORATION TO DEAL WITH THE PANDEMIC OF COVID-19}

The Costa Rican Social Security Fund and the Ministry of Health have been two key institutions for managing the pandemic. As a statement of both principle and practice, both institutions stated that people are not served according to nationality, but by health needs. This is an element of great relevance because Costa Rica is a country where there is a significant foreign population that is linked to agricultural production, construction and domestic services, but who are not necessarily insured. That is why the first decision was not to generate any discrimination in access to health services.

Other institutions that have collaborated are the Mixed Institute for Social Assistance (IMAS) and the National Emergency Commission (CNE) that coordinates all actions in the face of the health emergency. Under the CNE are all strategic institutions such as the National Institute of Women, the National Children's Trust, the National Insurance Institute, a large number of public companies such as Aqueducts and Sewers and the Costa Rican Electricity Institute. A most important issue is access to drinking water and there is a commitment by public companies not to suspend services during this national emergency.

The Costa Rican Electricity Institute has begun to provide services as an information platform so that people can have accurate information on issues related to the pandemic and the National Liquor Factory -which is also a public company- has become the largest supplier of alcohol and antiseptic solutions for the entire population, at affordable prices, as a central element for hygiene. 
The Ministry of Public Security has been in permanent protection of the borders, in order to make a sanitary fence to take care of the public health of all the people who live in Costa Rica and not allow irregular ingress.

Such multi-agency action requires coordination. Leadership was provided by the National Emergency Commission, which through a high-level committee makes daily decisions and is empowered to invest a large amount of economic resources and transfer humanitarian aid.

It is through this operational commission that the health responses that should be given at the territorial and national levels are monitored. The Commission, together with the Ministry of Health have clearly defined leadership on this issue. This structure allows for effective responses to a reality that, clearly, was unexpected.

\section{THE HEALTH SYSTEM AND THE PUBLIC}

Costa Rican citizens recognize health institutions as the most relevant and strongest institutions in the country, even though they might not have had to receive health services as a result of the pandemic. It is a deserved recognition. It was not born as a result of the pandemic, but came as a result of the long and devoted work carried out by these institutions in the country.

The pandemic has emphasized the need for information. The Government of the Republic has held press conferences every day since March 6 when the first case of COVID-19 was detected in the country. The press conference is accessible to the public through the social network pages of the Government of Costa Rica, along with posted information that people can consult at any time.

A part of this information is also transmitted through the media, which contributes to educating the population. This communication, instead of sowing fear, makes the Costa Rican population more informed, allowing them to make decisions that are important for their own health and for that of the community.

\section{SUSTAINABLE DEVELOPMENT}

Actions to improve health and to reduce inequities are consistent with the Sustainable Development Goals. Of central importance, Costa Rica has presented an ambitious National Decarbonization Plan to convert $100 \%$ of fossil fuel use to renewable energy. Already, today, in terms of electricity, the country is practically autonomous, relying mainly on clean energy. The next challenge for decarbonization is transportation, one of the elements on which Costa Rica is currently working.

The National Health Plan requires an absolutely clear response to situations such as the pandemic and associated problems. There is need for investment in health education. Certainly, education of the public has helped the health authorities to have a scientifically responsible approach to this pandemic.

\section{LESSONS FROM COSTA RICA FOR OTHER COUNTRIES IN THE REGION}

Costa Rica is suitably modest and would reflect on, and reaffirm, what it has done, rather than give prescriptions to others with different histories and realities. The Costa Rica experience shows that after a threshold of economic growth is reached, further economic growth is not necessary to achieve health success. Costa Rica's life expectancy of 80 (2018 UNDP figures) puts it in the middle of the range for countries rated as 'Very High' development.

The decision in the 1940s to abolish the military and invest in clean water, education and health care, and the well-being of the population, have been of great importance for the improvement in health of the population.

Within that context, the development of the health care system has been vital. Health policies have been at the center of development policies. Costa Rica has a supportive health system, where work is done not only on immediate care but also by levels. The first level starts from the logic of containing and addressing health problems before patients require hospitalization. Hundreds of basic care teams throughout the country are in the communities and look for people to generate their health records. This work greatly facilitates the approach in times of pandemic.

Disclaimer. Authors hold sole responsibility for the views expressed in the manuscript, which may not necessarily reflect the opinion or policy of the RPSP/PAJPH and/or the Pan American Health Organization.

\section{REFERENCES}

1. United Nations Development Programme. Human Development Indices and Indicators 2018 Statistical Update. New York: United Nations Development Programme; 2018.

2. Pan American Health Organization. Just Societies: Health Equity and Dignified Lives - Report of the Commission of the Pan American Health Organisation on Equity and Health Inequalities in the Americas. Washington DC: Pan American Health Organization; 2019.

Manuscript received on October 1 2020. Not peer-reviewed; accepted for publication on October 162020. 


\section{Liderazgo, determinantes sociales de la salud y equidad en salud: el caso de Costa Rica}

RESUMEN Costa Rica es un país de especial interés en las Américas y en la salud mundial debido a su buena salud. El Programa de las Naciones Unidas para el Desarrollo clasifica a los países según su nivel de desarrollo humano con base en la esperanza de vida, la educación y el ingreso nacional. Aunque Costa Rica está clasificada en el puesto 63 y clasificada dentro del grupo 'Alto', en términos de salud pertenece al grupo 'Muy alto'. En 2018 la esperanza de vida media de los países del grupo 'Muy alto' era de 79,5 años, mientras que en Costa Rica era de 80. En 2018, la mortalidad en menores de cinco años era de 8,8/1000 nacidos vivos, inferior a la de los países clasificados en el grupo de desarrollo humano 'Muy alto'. Los años de escolaridad esperados en Costa Rica son 15,4, más cercanos al promedio, 16,4 años, del grupo de desarrollo humano 'Muy alto' que el promedio del grupo 'Alto'. El país es mucho más saludable de lo que podría predecirse por su ingreso nacional; más bien, es probable que otras características del desarrollo de la sociedad hayan desempeñado un papel fundamental en el desarrollo de la buena salud. Entre ellas figuran: (i) la decisión de dejar de invertir en la defensa nacional, que liberó dinero para invertir en salud, educación y bienestar de la población; (ii) la decisión de crear un sistema de salud universal financiado por el Estado, los empleadores y los trabajadores en el decenio de 1940; y (iii) el sistema educativo, que generó oportunidades para sacar de la pobreza a importantes sectores de la población, permitiéndoles disponer de condiciones sanitarias básicas que aumentan sus posibilidades de vivir más y en mejores condiciones. A pesar de estos avances, persisten desigualdades en términos de ingresos y condiciones sociales, lo que plantea desafíos en el ámbito de la salud, en particular para las poblaciones de menores ingresos y las de ascendencia africana e indígena. Estas desigualdades deben abordarse mediante decisiones basadas en pruebas científicas, un mayor uso de datos desagregados que revelen los progresos realizados para hacer frente a esas desigualdades, y una mayor articulación del sector de la salud con las políticas que actúan sobre los determinantes sociales de la salud.

Palabras clave Equidad en salud; determinantes sociales de la salud; desarrollo humano; esperanza de vida; Costa Rica. 